\title{
Biofiltration Efficiency of Algae Spirogyra hyalina to Reduce Salinity of Sea Water
}

\section{Apriliya Maipa ${ }^{1}$, Siti Mushlihah ${ }^{2}$, Ayu Wulandari $^{1}$, Nur Qalbi $^{1}$, Ayub Wirabuana $^{1}$ and Ulfah Ervita $^{3}$}

${ }^{1}$ Department of Biology, Faculty of Mathematics and Natural Sciences, Hasanuddin University, Makassar, Indonesia

${ }^{2}$ Department of Environmental Engineering, Institut Teknologi Sepuluh Nopember, Surabaya, Indonesia

${ }^{3}$ Department of Public Health, Faculty of Public Health, Hasanuddin University, Makassar, Indonesia

\begin{abstract}
Algae Spyrogyra hyalina is one species of fresh water algae that is very easy to find in Indonesia. This species of algae known to have a lot of potential, which until now unknown. One potential that tried to explore in this research is the ability of these algae for decreasing the level of salt water salinity into fresh water. This research is an experiment with a completely randomized design (CRD), three treatments and three replications. Testing is done by performing algae arbsorbtion using three forms (powder, granule, and paper) with different biomass $(1 \mathrm{~g}, 2 \mathrm{~g}$, and $4 \mathrm{gr})$. Preparations then coupled into a transparent pipe. The results showed the real effect of the decreased levels of salinity brine through the circuit. Filter with the powder forms with $4 \mathrm{gr}$ biomass has the highest salinity level reduction of $15 \%$, then the dosage form of granules with biomass $4 \mathrm{gr}$ with decreased $5.23 \%$ o and the third dosage form of paper with 1 gram of biomass with a decrease of $4.23 \%$.Forms with other biomass have a decrease in the salinity level of not more than $4 \%$ o. Preparations with powder form and $4 \mathrm{gr}$ biomass can be used to reduce the salinity level in the salt water.
\end{abstract}

Article History

Received 23 May 2017

Accepted 10 July 2017

\section{Keyword}

Biosorpsion,

Salinity,

Sea Water, Spirogyra hyalina.

Nicotine,

Algae.

\section{Introduction}

Waters are the basic need of human being. In fact, not all countries have many water resources that can be consumed. Coastal areas and small islands in the middle of the seas only have a few fresh water resources. Thus, this condition can cause the problem of water supply. But if we try to see from different point of view, these area have many sources of water that come from the sea, although it can not be directly consumed because the excessive in salinity (Asmara \& Hasanuddin, 2012). The various ways of increasing the quality of water have been applied, such as - ion exchange, absorption, membrane technology, reverse osmosis, electrochemistry process, and solvent extraction. Those methods can separate metal in excessive numbers relatively, but they are judged not yet effective and uneconomical because need the high cost (Mawardi et al., 2014). 
Based on this problem, one of the appropriate method for processing the salt water that source from the sea into fresh water is can be conducted by using local plant biodiversity that widely available in Indonesia. One of the biodiversity in Indonesia is algae Spirogyra which can be easily found in this country and also easily to be found in fresh waters area on the excessive numbers (Oktaviani, 2014).

Algae Spirogyra has a shape of irregular surface texture and consists of amino acid, amide, carboxylic, hydroxyl and carbonyl group that are capable for binding a wide range of heavy metals (Singh et al., 2012), such as the use of green algae Spirogyra biomass as biosorbent of heavy metals like as - kation Cu2+, $\mathrm{Zn} 2+, \mathrm{Pb} 2+$ and $\mathrm{Cr} 6+$ in solution (Gupta \& Rastogi, 2008; Mawardi, 2011; Lee \& Chang, 2011; Mawardi et al., 2014). Kumar \& Oommen (2012), found out that dried Spirogyra biomass have many potentials as biosorbent to absorb cadmium ( $\mathrm{Cd}$ ), mercury ( $\mathrm{Hg}$ ), lead ( $\mathrm{Pb}$ ), arsenic (As) and cobalt (Co) from liquid solution which are emphasized on the difference of heavy metals concentrations and contact time of biomass. Furthermore, algae Spirogyra can reduce organic waste of Anguilla sp cultivation (Apriadi et al., 2014) and also textile dye (Khalaf, 2008). Research on the utilization of algae Spirogyra hyalina as an agent in the salt water filtration into fresh water has a potential. This study aims to determanie the potential of Spyrogyra hyalina in different form and different biomass for decreasing the salinity level of water (salt water into fresh water).

\section{Materials and Methods}

\section{Algae Culturing}

Algae Spirogyra hyalina took from the Hasanuddin University lake $\left(05^{\circ} 13^{\prime} 81,58^{\prime} \mathrm{S}^{\prime}\right.$ $\left.; 119^{\circ} 48^{\prime} 81,17^{\prime} \mathrm{E}\right)$. Algae Spirogyra hyalina that obtained then identified by manual identification of Zarina et al. (2007), to make sure of the species. Algae Spirogyra hyalina cultured in a medium using a glass aquarium with artificial lighting using 3,000 Lux flouresence light (Duration of lighting 12 hours of light and 12 hours of dark). For algae culturing that used growth medium $\left(\mathrm{KNO}_{3} 40 \mathrm{mg} / \mathrm{L}, \mathrm{P}_{2} \mathrm{O}_{5} 30 \mathrm{mg} / \mathrm{L}, \mathrm{K}_{2} \mathrm{O} 30 \mathrm{mg} / \mathrm{L}, \mathrm{MgSO}_{4} 2 \mathrm{mg} / \mathrm{L}\right.$. $\mathrm{Ca}\left(\mathrm{NO}_{3}\right) .4 \mathrm{H}_{2} \mathrm{O} 2$ $\mathrm{mg} / \mathrm{L}$ and micronutrient). Algae were cultured for 15 days with the addition of growth medium every 5 days (fed-batch culture).

\section{Pretreatment}

\section{Algae Powder}

Alga Spirogyra hyalina which have been harvested then dried using an oven at $80^{\circ} \mathrm{C}$ for 24 hours. Algae Spirogyra hyalina then crushed using a hand mixer into powder form of Spirogyra hyalina with particle sizes up to 40 mesh.

\section{Algae Granules}

50 grams of Spirogyra hyalina powder are poured with $100 \mathrm{~mL}$ water and mixed by using hand mixer for 10 minutes. After that, algae were filtered by using silk-screening. Algae which have been filtered then poured into spons which have been layered by fabric. Algae which have been on the fabric were covered by wet fabric and pressed by using the board. After getting dried, those algae were formed into granules.

\section{Algae Paper}

50 grams of Spirogyra hyalina powder are poured with $100 \mathrm{~mL}$ water and mixed by using hand mixer for 10 minutes. After that, algae were filtered by using silk-screening. Algae which have been filtered then poured into spons which have been layered by fabric. Algae 
which on the fabric were covered by wet fabric and pressed by using the board until getting dried, thus algae in form of paper was gotten. Algae which have been in form of paper were used as biosorbent.

\section{Data Collection}

Data collection of this research was conducted by doing direct observation to algae Spirogyra hyaline which are given the specific treatment. These observations were made by measuring the salinity of sea water before and after poured into the pipe which has been modified in such a way.

\section{Analysis of Data}

Data processing in this research were obtained using Analysis of Variance (ANOVA). Methods of Analysis of Variance (ANOVA) was used to determine the effect of different forms of algae Spirogyra hyalina in absorbing salt water into fresh water and comparing the effectiveness of algae Spirogyra hyalina based on the quantity of absorbent

\section{Results and Discussion}

The use of algae Spirogyra hyalina as biosorbent for salt water filtration into fresh water has considerable potential. From the results obtained, the salt water which early salinity is $25 \%$, decreased after tested using algae Spirogyra hyalina biorsorbent. Algae powder with $4 \mathrm{~g}$ biomass show significant gains compared to stocks and other biomass. The analysis also showed that most algae biomass which are 4 grams have a real effect in reducing the salinity brines. This shows that algae biomass as effective biosorbent in decreasing the salinity of salt water if in doing further testing allows to obtain fresh water. The results of ANOVA shows that there is an influence ( $\mathrm{H}_{1}$ Accepted), thus the test continued to Duncan test.

From the results of ANOVA test which is continued with duncan test with $95 \%$ believed range, it was known that from three kinds of treatment which are given to the algae extract did not give any real differences because all of this treatment being in the same subset.

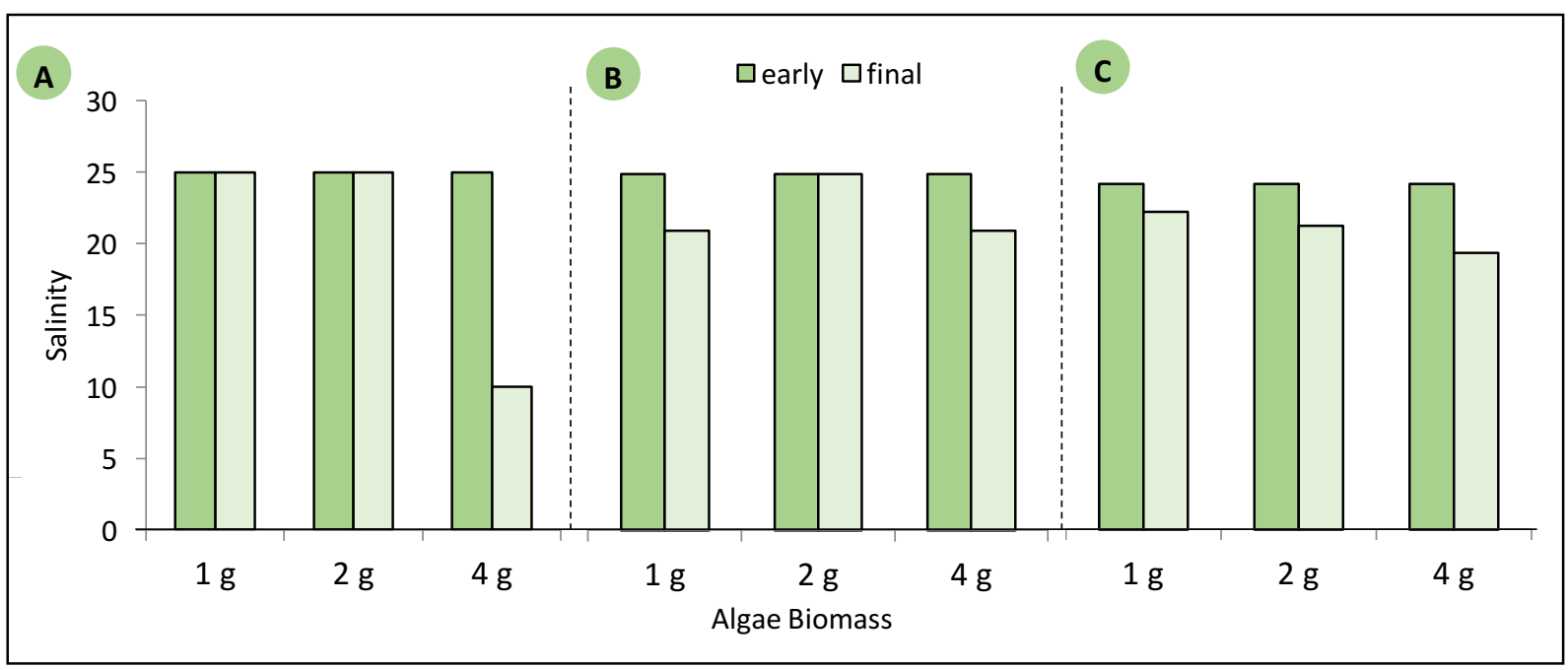

Figure 1. Average of Salinity in Different Form

(A. Powder, B. Paper and C. Granule) 


\section{Discussion}

This research was conducted by using three masses variation and three forms variation. Mass variation is given in a dose of 1 gram, 2 grams and 4 grams, while algae forms that were given are powder, paper and granules and repeated 3 times using salt water that has a beginning salinity $25 \%$. Based on the data obtained from this treatment as in the table above, the results of ANOVA analysis showed algae biomass has significant results or real influence on the decrease of salinity $(F<0.05)$, whereas no significant algae form $(F>0.05)$.

Duncan test showed the effect of form and the number of algal biomass Spirogyra hyalina to the salinity. The algae powder average of final salinity is $20 \mathrm{ppm}$, algae paper average salinity is $21 \mathrm{ppm}$ and algae granules average is $21.44 \mathrm{ppm}$. It showed that there is no significant difference in the differences of algae form to salinity decrased level. While in the biomass, algae with biomass $1 \mathrm{~g}, 2 \mathrm{~g}$, and $4 \mathrm{~g}$ obtained 22.78, 22.78, and 16.89 average of final salinity. Duncan analysis showed that the real effect from 4 grams biomas of algae in the powder forms is the best form for reducing salinity.

From the results that showed in figure 1, the algae mass that used in every form had an influence to decrease salt water salinity level. That mean higher biomass that used to decreasing salinity level will be very effected, and that mean the effectiveness of salinity biosorption can be increased. Every form that used in this research, show us the difference of effectiveness in decreasing salinity level. The powder form is the most effecive form that can be used as biosorben. Both of this result supported by Oscik \& Cooper (1992), that explain the active sites number is as large as biosorbent area and every active sites can only adsorb one adsorbat molecule. In condition where the adsorbtion area was saturated the biosorbent can not maximalized number of compound that adsorb.

Study about Algae Spirogyra in biosorption. Algae Spirogyra can be used in water treatment (Gupta et al., 2006; Sulfahri \& Manuhara., 2013), waste water treatment (Rajfur et al., 2012; Sulfahri et al., 2016), for water monitoring (Koanga et al., 2008; Sulfahri et al., 2017), and can be used for heavy metal waste that very commercil to published (Singh et al., 2012; Sulfahri et al., 2017). All of this study show us that Algae Spirogyra can be used as water treatment. Every study said that this kind of algae can adsorb any compound that dissolved in water, such as $\mathrm{Pb}$ and $\mathrm{Cu}$. We know that salt water contain Salt which made from chemical reaction of $\mathrm{Na}^{+}$and $\mathrm{Cl}^{-}$. The result of this research show us this algae can reduce the salinity level of salt water which can be meant this algae can adsorb $\mathrm{Na}$ and $\mathrm{Cl}$ that dissolved in salt water. In the future, this kind of algae can be used to reduce salinity level of salt water. This mean it can be a solution for lack of fresh water in certain area, especially in the island that fresh water source can not easily to be found.

\section{Conclusions}

The effectiveness of algae Spirogyra hyalina as biosorbent with some variations in preparations to decrease the salinity level of seawater can be seen from the results of sea water salinity level changes before and after treatment.

\section{Acknowledgment}

The authors gratefully acknowledge financial support from the Ministry of Research, Technology and Higher Education of Indonesia with project PKM (Program Kreativitas Mahasiswa) contract number 547/B3.1/KM/2017. 


\section{References}

Apriadi, T., Niken, TM., P. \& Sigid, H. 2014. Phytoremediation of wastewater of Anguilla sp. Cultivation by Using Filamentous Algae (Spirogyra sp.). Depik, 3(1):46-55.

Asmara, B. \& Hasanuddin, P. 2012. Training in Making Desalinisation of Sea Water in to Fresh Water by Using The Spider's Nest Method for Society of Olele Village, Kabila District, Regency of Bone Bolango. Journal of Sibermas, 6(2):82-86.

Gupta V.K., Rastogi A., Saini, V.K. \& Jain N. 2006. Biosorption of Cu(II) from aqueous solutions by Spirogyra species. J. Colloid Interface Sci. 296:59-63.

Gupta V.K. \& Rostogi, A. 2008. Biosorption of lead from aqueous solutions by green algae Spirogyra species: kinetics and equilibrium studies. J. Hazard. Mater. 152:407-414

Khalaf, M.A. 2008. Reactive Dye from Textile Wastewater by Non-Viable Biomass of Aspergillus niger and Spirogyra sp. Bioresource Technology. 99:6631-6634.

Kumar, N. \& Oommen, C. 2012. Removal of Heavy Metals by Biosorption Using Fresh water Alga Spirogyra hyalina. Journal of Environmental Biology. 33:27-31.

Lee, Y.C. \& Chang, S.P. 2011. The biosorption of Heavy Metals from Aqueous Solution by Spirogyra and Cladophora filamentous macroalgae. Bioresource Technology. 102:52975304.

Mawardi. 2011. Biosorpstion of Kation Cu (II) and Fe (II) by Using Biomass Green Algae Spirogyra subsalsa, Biota. 16(2):269-277.

Mawardi, Nazulis, Z. \& Kurniawati, D., 2014, Review Process Biosorption Lead (II) By Algae Spirogyra Subsalsa Biomass Through Modification of Carboxyl and Carbonyl groups. Bionatura. 16(2): $114-118$.

Oscik, J. \& Cooper, I. L. 1992. Adsoption Horwood Publisher Limited, Chichester.

Oktaviani, R., Fida, R. \& Wisanti. 2014. The Potential of Pistia stratiotes and Spirogyra as Phytoremediation Agent of Heavy Metal Lead (Pb) in Waters, LenteraBio, 3 (3): 276-181.

Rajfur, M., Klos, A., Waclawek, M. 2012. Sorption of Copper(II) lons in the Biomass of Alga Spirogyra sp. Bioelectrochemistry. 12(7):65-70.

Singh, A., Kumar, D. \& Gaur, J.P. 2012. Continuous Metal Removal from Solution and Industrial Effluents Using Spirogyra Biomass-packed Column Reactor, Water Research. 46:779-788.

Sulfahri \& Manuhara, S.W. 2013. Effect of Salinity and Gandasil-D on Spirogyra hyalina Biomass in Non-Aerated Culture. Journal of Applied Phytotechnology in Environmental Sanitation. 2 : 53-58.

Sulfahri, Amin, M., Soemitro, S.B. \& Saptasari, M. 2017. Comparison of Biomass Production from Algae Spirogyra hyalina and Spirogyra peipingensis. Biofuels. 8(3):359-366.

Zarina, A., Hasana, M.U. \& Shameel, M. 2007. Diversity of the Genus Spirogyra (Zygnemophyceae Shameel) in the North-Eastern Areas of Pakistan. Proceedings of The Pakistan Academy of Sciences. 44 (4) : $225-248$.

\section{To cite this article:}

Maipa, A., Mushlihah, S., Wulandari, A., Qolby, N., Wirabuana, A. \& Ervita, U. 2017. Biofiltration Efficiency of Algae Spirogyra hyalina to Reduce Salinity of Sea Water. International Journal of Applied Biology. 1(1):9-13. 